AperTO - Archivio Istituzionale Open Access dell'Università di Torino

Chromosomal damage in peripheral blood lymphocytes from nurses occupationally exposed to chemicals

This is a pre print version of the following article:

Original Citation:

Availability:

This version is available http://hdl.handle.net/2318/139278

since 2016-03-11T12:00:09Z

Published version:

DOI:10.1177/0960327113512338

Terms of use:

Open Access

Anyone can freely access the full text of works made available as "Open Access". Works made available under a Creative Commons license can be used according to the terms and conditions of said license. Use of all other works requires consent of the right holder (author or publisher) if not exempted from copyright protection by the applicable law. 


\section{Author Query Form}

\section{Human and Experimental Toxicology}

Paper Number: 512338

Please ensure that you have obtained and enclosed all necessary permissions for the reproduction of artistic works, (e.g. illustrations, photographs, charts, maps, other visual material, etc.) not owned by yourself, and ensure that the Contribution contains no unlawful statements and does not infringe any rights of others, and agree to indemnify the Publisher, SAGE Publications Ltd, against any claims in respect of the above warranties and that you agree that the Conditions of Publication form part of the Publishing Agreement.

Author queries

\begin{tabular}{|l|l|c|}
\hline No. & Query & Author reply \\
\hline 1 & Please provide location details for the supplier 'Difco'. & Difco, U.S.A. \\
\hline 2 & Please provide accessed date for Ref 16. & november 2012 \\
\hline
\end{tabular}




\title{
Chromosomal damage in peripheral blood lymphocytes from nurses occupationally exposed to chemicals
}

Human and Experimental Toxicology 20IX, Vol $X X(X)$ I-7 (C) The Author(s) 2013 Reprints and permission: sagepub.co.uk/journalsPermissions.nav DOI: 10.1|77/0960327||35/2338 het.sagepub.com (SAGE

\author{
A Santovito, P Cervella and M Delpero
}

\begin{abstract}
In the present study, we evaluated the induced genome damage in peripheral blood lymphocytes from a sample of nurses occupationally exposed to low doses of different chemicals. A comprehensive multi-biomarker approach using cytogenetic endpoints was employed for analyzing chromosomal aberrations (CAs) and sister chromatid exchange (SCE) assay. The study included 20 nurses and 20 control subjects matched in age, gender and smoking habits. Nurses were exposed to different chemicals, such as cytostatic drugs, anaesthetics, formaldehyde and other sterilizing gases. Significant differences were found between exposure group and control group in terms of SCEs frequency $(p<0.00 \mathrm{I})$ but not in terms of replication index value $(p=0.845)$ and CAs $(p=0.236)$. Regression analyses indicated that the age and the exposure years did not influence the amount of the chromosomal damage among nurses. Vice versa, among controls, a positive correlation was found between the number of SCEs and age. In conclusion, our results suggest that a continuous long-term exposure to low doses of chemicals could result in increased levels of SCEs among nurses. This data emphasize the importance of biomonitoring nurses and other hospital workers handling drugs.
\end{abstract}

\section{Keywords}

Nurses, SCE assay, chromosomal aberrations, occupational exposure

\section{Introduction}

At the workplace, nurses are exposed to a wide spectrum of different drugs in sub-therapeutic concentrations, with unknown biological consequences. In general, occupational exposure to cytostatic drugs, anaesthetic and sterilizing gases with potential mutagenic and carcinogenic capacity is a major hazard for the health care personnel.

For example, ethylene oxide and formaldehyde, used for sterilization, are well-known human carcinogens and are related to an increase of both chromosomal aberrations (CAs) and sister chromatid exchanges (SCEs) among exposed subjects. ${ }^{1,2}$ Moreover, some of antineoplastic drugs (including alkylating agents, antimetabolites, antibiotics and hormones) used for the treatment of various types of cancer and immunologic diseases have been classified to be carcinogenic to humans according to their mutagenic and clastogenic properties. 3,4

It is known that formaldehyde and antineoplastic drugs induce reactive oxygen species (ROS) that can cause DNA strand breaks, alteration in bases and chromosomal rearrangements. Moreover, ROS can affect cell function by acting directly not only on DNA but also on lipids and proteins, thereby destroying the cellular structure. ${ }^{5}$ Antineoplastic drugs are a heterogeneous group of compounds (such as alkylating agents, metabolic antagonists, antibiotics, mitotic spindle inhibitors, hormones etc) able to inhibit tumour growth by disrupting cell division and actively killing growing cells. These compounds interact with DNA inhibiting the activities of topoisomerase I and II $^{6,7}$ and inducing double- and single-strand breaks, cross-links and alkylations. ${ }^{8}$

Department of Life Sciences and Systems Biology, University of Turin, Torino, Italy

\section{Corresponding author:}

Alfredo Santovito, Department of Life Sciences and Systems Biology, University of Turin, Via Accademia Albertina n. 13, I0I23 Torino, Italy.

Email: alfredo.santovito@unito.it 
Table I. Demographic characteristics of the studied groups.

\begin{tabular}{llccccr}
\hline \multirow{2}{*}{ Groups } & $N$ & \multicolumn{2}{c}{ Age } & & \multicolumn{2}{c}{ Exposure years } \\
\cline { 3 - 4 } & & Mean \pm SD & Range & & Mean \pm SD & Range \\
\hline Nurses & 20 & $37.350 \pm 11.775$ & $21-58$ & & $11.850 \pm 7.184$ & $1-28$ \\
Department I & 10 & $33.900 \pm 11.775$ & $21-50$ & & $10.300 \pm 7.103$ & $1-22$ \\
Department 2 & 10 & $40.800 \pm 12.309$ & $23-58$ & & $13.400 \pm 7.291$ & $1-28$ \\
Controls & 20 & $39.650 \pm 5.344$ & $32-53$ & & $11.200 \pm 3.205$ & $7-20$ \\
$\quad$ Department I & 10 & $39200 \pm 6.512$ & $32-53$ & & $11.300 \pm 3.802$ & $7-20$ \\
Department 2 & 10 & $40.100 \pm 4.175$ & $34-47$ & & $11.100 \pm 2.685$ & $7-15$ \\
\hline
\end{tabular}

SCEs occur as a consequence of interchanges between DNA replication products at apparently homologous chromosomal loci and these exchanges involve DNA breakage and reunion. ${ }^{9}$ SCEs are induced by those agents forming covalent adducts to DNA or otherwise interfere with DNA metabolism and repair. CAs reflect damage occurred during the $G_{1}$ phase in regions that have not undergone repair or have evolved to a rearranged element. CAs are breaks, acentric fragments, rings, dicentrics and interchromosomal exchanges, which are often unstable aberrations and will lead to cell death during proliferation. ${ }^{10}$ Generally, SCE analysis represents a more sensitive test, particularly for $S$ phase-dependent agents (e.g. alkylating agents), allowing to detect genotoxic effects at much lower concentrations than those required to induce CAs. ${ }^{11}$

Hospital workers might be exposed to drugs throughout their use in health care environments. This occupational exposure may occur in different ways, such as inhalation of airborne agents, absorption through skin contact, ingestion during drug preparation and/or contact with the patient's body fluids. ${ }^{12-14}$

To minimize the risk of occupational exposure, several guidelines and safety recommendations for the handling of different drugs were issued. ${ }^{15,16} \mathrm{Nev}$ ertheless, despite the adoption of these guidelines in health care institutions, published reports suggest that some health care workers do not follow the standards established by their employers, putting themselves at risk for mutagenicity. ${ }^{17}$

In this scenario, the use of biomonitoring processes among personnel with potential worksite exposure is of primary interest in biological safety. Some cytogenetic studies have proven an increased number of CAs, SCEs and gene mutations among nurses and other hospital workers. ${ }^{6,18-21}$ Nevertheless, other studies resulted to be ambiguous, probably because of different exposure conditions and because some confounder factors, such as smoking habits and/or alcohol abuse, were not always properly taken into account. $^{22,23}$

In the present study, we evaluated the incidence of CAs and SCEs in a sample of hospital nurses that used complete protective equipment and that have neither smoked nor consumed alcohol or drugs at least 2 years before analysis. The aim of the study was to evaluate the eventual genotoxic damage of nurses chronically exposed to low doses of different drugs. As expected, the results of this study might be potentially useful in the implementation of intervention measures aimed to minimize genotoxic risks and eliminate or significantly reduce worker exposure.

\section{Methods}

\section{Study population}

The study included 20 female nurses from 2 analogous departments of 2 different hospitals and 20 female control subjects belonging to the administrative staff and working at the same hospitals without any work-related exposure to hazardous agents. Demographic characteristics of the studied groups are reported in Table 1.

The nurses were exposed to different chemicals: mainly antibiotics and sporadically cytostatic drugs (cyclophosphamide, ifosfamide, 5-fluoro-uracil etc), anaesthetic and sterilizing gases such as ethylene oxide and formaldehyde. All nurses used complete protective equipment, according to the Italian guidelines and were routinely tested for urinary and blood drugs concentrations. In our sample, we exclusively considered individuals who have not smoked nor consumed drugs and have not been subjected to diagnostic examinations for a period of at least 2 years prior to the analysis. All the subjects were healthy volunteers, received information about the study and were extensively interviewed by a specialized physician with a 
detailed questionnaire in order to provide important information for the study. The procedures followed in this work were in agreement with the ethical standards of the local responsible committee on human experimentation and have been performed in accordance with the ethical standards laid down in the 1964 Declaration of Helsinki.

\section{Blood sample collection and cell cultures}

Blood samples were obtained by venipuncture (5-10 $\mathrm{ml}$ ) and collected into heparinized tubes for genotoxicity testing. All blood samples were coded, cooled $\left(4^{\circ} \mathrm{C}\right)$ and processed within $2 \mathrm{~h}$ after collection.

Heparinized venous blood $(0.3 \mathrm{ml})$ was cultured in $25 \mathrm{~cm}^{2}$ flasks in $6 \mathrm{ml}$ RPMI-1640 (Biological Industries, Israel) supplemented with $20 \%$ fetal calf serum, $2 \%$ of the mitogenic agent phytohemagglutinin-M (Dif $\bigcirc 0.2 \mathrm{ml})$, L-glutamine $(2 \mathrm{mM})$ and antibiotics (100 IU/ml penicillin and $100 \mu \mathrm{g} / \mathrm{ml}$ streptomycin). The cultures were incubated for $48 \mathrm{~h}$ for CAs assay and $72 \mathrm{~h}$ for SCEs assay, at $37^{\circ} \mathrm{C}$ in an atmosphere of $5 \%$ carbon dioxide in air. To arrest cells in mitosis, colchicine $(0.25 \mu \mathrm{g} / \mathrm{ml}$; Sigma, St Louis, Missouri, USA) was added at a concentration of $0.06 \mu \mathrm{g} / \mathrm{ml}$ during the last $2 \mathrm{~h}$ of culture. Chromosome preparation was carried out following standard procedures. Cells were centrifuged at $1000 \mathrm{r} / \mathrm{min}$, slowly resuspended in $10 \mathrm{ml}$ of pre-warmed hypotonic solution $(0.075$ $\mathrm{M}$ potassium chloride, pre-warmed to $37^{\circ} \mathrm{C}$ ), and incubated for $15 \mathrm{~min}$ in a $37^{\circ} \mathrm{C}$ water bath. The cells were centrifuged at $1000 \mathrm{r} / \mathrm{min}$ again and fixed in cold methanol:acetic acid (3:1) for $20 \mathrm{~min}$ at room temperature. The treatment with the fixative was repeated three times. Finally, the supernatant was discarded; and the pellet, dissolved in a minimal volume of fixative, was seeded on the slides.

\section{CAs assay}

Air-dried slides were stained for 20 min with $5 \%$ Giemsa stain ( $\mathrm{pH}$ 6.8) prepared in a Sörensen buffer. For each subject, a total of 200 well-spread metaphases were analysed for the following categories of CAs: chromatid breaks $\left(\mathrm{B}^{\prime}\right)$, chromosome breaks $\left(\mathrm{B}^{\prime \prime}\right)$, dicentrics (Dic), acentric fragments $(\mathrm{AF})$, rings (R) and tri- or tetra-radials (TR). Gaps (a-chromatid lesions) were not scored as CAs. Cells containing any type of CAs were scored as cells with aberrations (CAB).

\section{SCEs assay}

To measure SCEs in second-division metaphases, bromodeoxyuridine (BrdU, $5 \mu \mathrm{g} / \mathrm{ml}$ ) was added at $24 \mathrm{~h}$. BrdU closely resembles thymidine and is efficiently incorporated into the elongating DNA strands during replication. After two cell cycles in BrdU medium, the two sister chromatids differ in the amount of BrdU present and the chromatid with more BrdU is lighter in appearance ('bleaching' effect).

For sister chromatid differentiation, the cells were stained with fluorescence dye Hoechst 33258 (Sigma, $10 \mu \mathrm{g} / \mathrm{ml}, 20 \mathrm{~min}$, at room temperature in the dark) and subsequently irradiated with an $8-\mathrm{W}$ ultraviolet lamp $(254 \mathrm{~nm})$ at a distance of about $20 \mathrm{~cm}$ for 30 min. Subsequently, the slides were incubated in $2 \times$ standard saline concentration for $1 \mathrm{~h}$ at $60^{\circ} \mathrm{C}$ and then stained with 5\% Giemsa (Sigma) in the Sörensen buffer for $10 \mathrm{~min}$. Microscopic analyses were performed at $1000 \times$ magnification on a light microscope (CX40, Olympus, Tokyo, Japan).

In order to determine the number of SCE/cell for each subject, we scored 50 well-spread seconddivision metaphases containing 46 chromosomes. A total of 100 cells from each donor were scored for the determination of the replication index (RI) and calculated according to the following formula: $\mathrm{RI}=\left(M_{1}+2 M_{2}+3 M_{3}\right) / N$, where $M_{1}, M_{2}$ and $M_{3}$ represent the number of cells undergoing first, second and third mitosis, and $N$ is the total number of scored metaphases (NSM).

\section{Statistical analysis}

Statistical analysis was assessed using the SYSTAT software statistical package programme (version 10.0, Chicago, Illinois, USA). A non-parametric Wilcoxon test was used to compare the mean frequencies of SCEs and CAs between nurses and controls. Multiple regression analysis was used to evaluate the influence of age and exposure years on SCEs and CAs frequencies of both groups. All $p$ values were twotailed; and the level of statistical significance was set at $p<0.05$ for all tests.

\section{Results}

No significant differences were found between groups in terms of mean age $(p=0.501)$ and exposure years $(p=0.825$; Table 1$)$.

Results of the SCE analysis are summarized in Table 2. Significant differences were found between 
Table 2. SCEs frequency and RI values in metaphases of lymphocytes from nurses and controls. ${ }^{\text {a }}$

\begin{tabular}{lcrrccccc}
\hline Groups & $N$ & NSM & SCEs & SCEs/NSM \pm SE & $M_{1}$ & $M_{2}$ & $M_{3}$ & $\mathrm{RI} \pm$ SE \\
\hline Nurses & 20 & 1000 & 6545 & $6.545 \pm 0.325^{\mathrm{b}}$ & 686 & 735 & 579 & $1.946 \pm 0.055$ \\
Department I & 10 & 500 & 3338 & $6.676 \pm 0.508$ & 335 & 372 & 293 & $1.958 \pm 0.082$ \\
Department 2 & 10 & 500 & 3207 & $6.414 \pm 0.431$ & 351 & 363 & 286 & $1.935 \pm 0.077$ \\
Controls & 20 & 1000 & 4101 & $4.101 \pm 0.37 I^{\mathrm{b}}$ & 651 & 829 & 505 & $1.945 \pm 0.044$ \\
$\quad$ Department I & 10 & 500 & 1991 & $3.982 \pm 0.566$ & 349 & 420 & 218 & $1.965 \pm 0.062$ \\
Department 2 & 10 & 500 & 2110 & $4.220 \pm 0.507$ & 302 & 409 & 287 & $1.925 \pm 0.066$ \\
\hline
\end{tabular}

N: number of individuals sampled; NSM: number of scored metaphases; SCEs: sister chromatid exchanges; SE: standard error; RI: replication index

${ }^{a} \mathrm{RI}=\left(M_{1}+2 M_{2}+3 M_{3}\right) / N$, where $M_{1}, M_{2}$ and $M_{3}$ represent the number of cells undergoing first second and third mitosis and $N$ is the total number of metaphase scored.

$\mathrm{b}_{p}<0.001$.

Table 3. CAs frequency in lymphocytes from nurses and controls.

\begin{tabular}{|c|c|c|c|c|c|c|c|c|c|c|c|c|}
\hline \multirow[b]{2}{*}{ Groups } & \multirow[b]{2}{*}{$N$} & \multicolumn{11}{|c|}{ Chromosome Aberrations } \\
\hline & & NSM & $\mathrm{B}^{\prime}$ & $\mathrm{B}^{\prime \prime}$ & Dic & $\mathrm{AF}$ & $\mathrm{R}$ & TR & Total CAs & Total CABs & $\begin{array}{c}\text { CAs/NSM } \\
(\text { mean } \pm \text { SE) }\end{array}$ & $\begin{array}{c}\mathrm{CAB} / \mathrm{NSM} \\
(\text { mean } \pm \mathrm{SE})\end{array}$ \\
\hline Nurses & 20 & 4000 & 43 & 31 & 2 & 19 & 2 & 4 & 101 & 99 & $0.0252 \pm 0.0030$ & $0.0247 \pm 0.0030$ \\
\hline Department I & 10 & 2000 & 24 & 15 & I & 10 & 0 & 2 & 52 & 50 & $0.0260 \pm 0.0050$ & $0.0250 \pm 0.0045$ \\
\hline Department 2 & 10 & 2000 & 19 & 16 & I & 9 & 2 & 2 & 49 & 49 & $0.0245 \pm 0.0040$ & $0.0245 \pm 0.0040$ \\
\hline Controls & 20 & 4000 & 47 & 9 & 5 & 18 & I & 0 & 80 & 78 & $0.0200 \pm 0.0030$ & $0.0195 \pm 0.0030$ \\
\hline Department I & 10 & 2000 & 23 & 5 & 2 & 9 & 0 & 0 & 39 & 39 & $0.0195 \pm 0.0050$ & $0.0195 \pm 0.0050$ \\
\hline Department 2 & 10 & 2000 & 24 & 4 & 3 & 9 & I & 0 & 41 & 39 & $0.0205 \pm 0.0050$ & $0.0195 \pm 0.0050$ \\
\hline
\end{tabular}

$N$ : number of individuals sampled; NSM: number of scored metaphases; $B^{\prime}$ : chromatid breaks; $B^{\prime \prime}$ : chromosome breaks; Dic: dicentric chromosome; AF: acentric fragments; R: ring; TR: tri- or tetra-radials; CAs: chromosomal aberrations; CAB: cells with aberrations; SE: standard error.

exposed and controls in terms of SCEs/NSM frequency $(p<0.001)$ but not in terms of RI value $(p=0.845)$. In either group, no statistical significant differences were found between departments in terms of SCEs/NSM ( $p=0.721$ among nurses and $p=0.508$ among controls $)$ and $\mathrm{RI}(p=0.799$ among nurses and $p=0.646$ among controls). Among nurses, regression analyses indicated that the age and the exposure years did not influence the amount of SCEs ( $p=0.609$ and $p=0.831$, respectively). Vice versa, in the control group, a positive correlation was found between SCEs/NSM and age ( $p=0.002$; Table 4$)$.

Results of the CA analysis are summarized in Table 3. No statistically significant differences were found between exposed and control subjects in terms of CAs/NSM $(p=0.236)$ and CAB/NSM $(p=0.266)$. Similar to SCEs results, in either group, no statistical significant differences were found between departments in terms of CAs/NSM $(p=0.725$ among nurses and $p=0.858$ among controls) and CAB/NSM ( $p=0.779$ among nurses and $p=0.858$ among controls).
Regression analyses indicated that the age and the exposure years did not influence the level of the CAs among both exposed $(p=0.829$ and $p=0.821$, respectively) and control ( $p=0.708$ and $p=0.572$, respectively) groups (Table 4). Finally, no significant differences were found between the two departments in terms of SCEs/NSM and CAs/NSM among both nurses and controls (Tables 2 and 3).

\section{Discussion}

Several published studies were focused on the occupational risks of nurses and other hospital workers due to the handling of several types of drugs. Despite the improvement of safety protection measures, the contamination via inhalation of drug aerosols and/or accidents during the preparation of potentially genotoxic/ mutagenic drugs cannot be completely excluded among nurses. ${ }^{24-26}$ Indeed, transient increases of SCEs and micronuclei (MNs) in cases of accidental contamination, ${ }^{23}$ as well as significantly increased 
Table 4. Multiple regression analysis of confounding factors on SCEs and CAs frequencies in peripheral lymphocytes of the study groups.

\begin{tabular}{|c|c|c|c|c|c|c|}
\hline \multirow[b]{2}{*}{$\mathrm{CF}$} & \multicolumn{3}{|c|}{ SCEs frequency } & \multicolumn{3}{|c|}{ CAs frequency } \\
\hline & $\beta$-со & $\mathrm{P}$-value & $95 \% \mathrm{Cl}$ Lower-Upper & $\beta$-со & $p$-Value & $95 \% \mathrm{Cl}$ lower-upper limit \\
\hline \multicolumn{7}{|l|}{ Nurses } \\
\hline Age & 1.680 & 0.609 & -5.140 to 8.499 & 0.029 & 0.829 & $-0.25 I$ to 0.308 \\
\hline $\mathrm{EY}$ & 1.117 & 0.831 & -9.816 to 12.050 & -0.112 & 0.821 & 0.497 to 0.399 \\
\hline Department & 28.153 & 0.430 & -45.512 to 101.817 & 0.349 & 0.810 & -2.671 to 3.368 \\
\hline \multicolumn{7}{|l|}{ Controls } \\
\hline Age & $|2.26|$ & 0.002 & 5.054 to 19.467 & -0.068 & 0.708 & -0.443 to 0.308 \\
\hline $\mathrm{EY}$ & -4.117 & 0.477 & -16.093 to 7.859 & 0.170 & 0.572 & -0.454 to 0.794 \\
\hline Department & -0.042 & 0.999 & -60.955 to 60.87 I & -0.295 & 0.846 & -3.468 to 2.879 \\
\hline
\end{tabular}

CF: confounding factor; $\beta$-co: $\beta$-coefficient; EY: exposure years; CAs: chromosomal aberrations.

rates of SCEs, CAs and MNs in occupationally exposed nurses, were observed. ${ }^{24,27,28}$

Although previous published studies have demonstrated a significant increase of CAs among hospital workers occupationally exposed to drugs, $24,27,29,30$ in the present study, no chromosomal damage, in terms of increase of the CAs and $\mathrm{CAB}$ frequencies, was observed among our nurses sample.

Vice versa, we found the frequency of SCEs has significantly increased. This finding confirms the results of previous investigations ${ }^{31,32}$ about occupationally exposed nurses, whereas for other hospital workers, such as pharmacy personnel, this pattern was not observed. ${ }^{23}$

Increased frequency of CAs is recognized as a potential predictor of cancer, ${ }^{33,34}$ whereas no clear association has been observed between high SCE frequencies and cancer risk. ${ }^{35,36}$ Increased levels of DNA damage are not necessarily associated with the onset of cancer since the damage actually measured is a consequence of the equilibrium between damage infliction and repair. In this scenario, the higher SCEs rate recorded among occupationally exposed subjects could be considered as a signal suggesting potential defects in DNA repair processes. ${ }^{10}$ Defects in cellular DNA repair have been linked to genome instability, heritable cancers, premature ageing syndromes and neurological diseases. ${ }^{37}$ Moreover, accumulation of DNA lesions in repair-defective individuals may cause cell death, either by progressively depriving the cell of vital transcripts or through apoptosis. ${ }^{38}$

Results obtained in this study indicate that age appears to influence the SCEs rate but not the CAs frequency among control subjects. This finding is in agreement with previously reported data on the age- related incidence of chromosomal damage among control populations. Indeed, while some authors did not find an increase of CAs with age, ${ }^{39,40}$ others reported a significant correlation between age and SCEs frequency in peripheral blood lymphocytes. $^{41-43}$ The lack of a similar pattern among the professionally exposed nurses could be due to a greater incidence of chromosomal damage among younger individuals.

Finally, we did not find a correlation between chromosomal damage and duration of exposure, which may reflect the fact that, during chronic exposure, part of the chromosomal damage is not detectable in vivo because of the death of lymphocytes.

\section{Conclusion}

Our results suggest that a continuous long-term exposure to low doses of chemicals could result in increased levels of SCEs among nurses. This data emphasize the importance of biomonitoring of nurses and other hospital workers handling drugs.

\section{Acknowledgements}

We are grateful to Dr Sergio Castellano and Mrs Natascha Rogge for their valuable help and criticism and to all volunteers who participated in this study. The authors are also thankful to the anonymous referees for their helpful comments and constructive suggestions.

\section{Conflict of interest}

The authors declared no conflicts of interest with respect to the authorship and/or publication of this article. 


\section{Funding}

This work was supported by grants from the Italian Ministry of University and Scientific Research (ex 60\%).

\section{References}

1. International Agency for Research on Cancer (IARC). Allyl Compounds, Aldehydes, Epoxides and Peroxides. In: Evaluation of the carcinogenic risk of chemicals to humans. Lyon, France: IARC, 1988; 36: 198-226.

2. Santovito A, Schilirò T, Castellano S, Cervella $P$, Bigatti MP, Gilli G, et al. Combined analysis of chromosomal aberrations and glutathione S-transferase M1 and T1 polymorphisms in pathologists occupationally exposed to formaldehyde. Arch Toxicol 2011; 85: 1295-1302.

3. International Agency for Research on Cancer (IARC). Evaluation of carcinogenic risk to humans: Pharmaceutical drugs. Lyon, France: IARC, 1990; 50.

4. International Agency for Research on Cancer (IARC). Some antiviral and antineoplastic drugs, and other pharmaceutical agents. In: Evaluation of carcinogenic risk to humans. Lyon, France: IARC, 1999; 76.

5. Halliwell B and Aruoma OI. DNA damage by oxygen-derived species: its mechanism and measurement in mammalian systems. FEBS J 1991; 281: 9-19.

6. Jakab MG, Major J and Tompa A. Follow-up genotoxicological monitoring of nurses handling antineoplastic drugs. J Toxicol Environ Health 2001; 62: 307-318.

7. Villarini M, Dominici L, Piccinini R, Fatigoni C, Ambrogi M, Curti G, et al. Assessment of primary, oxidative and excision repaired DNA damage in hospital personnel handling antineoplastic drugs. Mutagenesis 2011; 26: 359-369.

8. Rombaldi F, Cassini C, Salvador M, Saffi J and Erdtmann B. Occupational risk assessment of genotoxicity and oxidative stress in workers handling anti-neoplastic drugs during a working week. Mutagenesis 2009; 24(2): 143-148.

9. Knudsen LE and Hansen ÅM. Biomarkers of intermediate endpoints in environmental and occupational health. Int J Hyg Environ Health 2007; 210: 461-470.

10. Garcia-Sagredo JM. Fifty years of cytogenetics: a parallel view of the evolution of cytogenetics and genotoxicology. Biochim Biophys Acta 2008; 1779(6-7): 363-375.

11. Chia KS and Lee HP. Occupational cancers. In: Koh D, Chia KS and Jeyaratnam J (eds) Textbook of occupational medicine practice (2nd ed) Singapore: World Scientific Publishing Co., P. Ltd., 2001, pp. 355-377.
12. Neal AW, Wadden RA and Chlou WL. Exposure of hospital workers to airborne antineoplastic agents. Am J Hosp Pharm 1983; 40: 597-601.

13. Hirst M, Tse S, Mills DG, Levin L and White DF. Occupational exposure to cyclophosphamide. Lancet 1984; 1: 186-188.

14. Ziegler E, Manson HJ and Baxter PJ. Occupational exposure to cytotoxic drugs in two UK oncology wards. Occup Environ Med 2002; 59(9): 608-612.

15. American Society of Hospital Pharmacists (ASHP). Guidelines on handling hazardous drugs. Am J Hosp Pharm 2006; 63: 1172-1193.

16. National Institute for Occupational Safety and Health (NIOSH). Alert: preventing occupational exposure to antineoplastic and other hazardous drugs in healthcare settings. Available at: http://www.cdc.gov/niosh/docs/ 2004-165, 2004.

17. Ritchie MA, Mc Adams $C$ and Fritz N. Exposure risk in the handling and administration of chemotherapy agents: a review and synthesis of the literature. Online J Knowl Synth Nurs 1999; 7: 1-10.

18. Norppa H, Sorsa M, Vainio H, Gröhn P, Heinonen E, Holsti L, et al. Increased SCE frequencies in lymphocytes of nurses handling cytostatic agents. Scand $J$ Work Environ Health 1980; 6: 299-301.

19. Nikula E, Kiviniitty K, Leisti J and Taskinen PJ. Chromosome aberrations in lymphocytes of nurse handling cytostatic agents. Scand J Work Environ Health 1984; 10: 71-74.

20. Chrysostomou A, Seshadri R and Morley AA. Mutation frequency in nurses and pharmasists working with cytotoxic drugs. Aust $N Z$ J Med 1984; 14: 831-834.

21. Anwar WA, Salama SI, El Serafy MM, Hemida SA and Hafez AS. Chromosomal aberrations and micronucleus frequency in nurses occupationally exposed to cytotoxic drugs. Mutagenesis 1994; 9: 315-317.

22. Sorsa M and Anderson S. Monitoring of occupational exposure to cytostatic anticancer agents. Mutat Res 1996; 355: 253-261.

23. Pilger A, Kohler I, Stettner H, Mader RM, Rizovski B, Terkola R, et al. Long-term monitoring of sister chromatid exchanges and micronucleus frequencies in pharmacy personnel occupationally exposed to cytostatic drugs. Int Arch Occup Environ Health, 2000; 73: 442-448.

24. Kopjar N, Garaj-Vrhocav V, Kašuba V, Rozgaj R, Ramić S, Pavlica V, et al. Assessment of genotoxic risks in Croatian healthcare workers occupationally exposed to cytotoxic drugs: a multi-biomarker approach. Int $J$ Hyg Environ Health 2009; 212(4): 414-431. 
25. Crauste-Manciet S, Sessink PJM, Ferrari S, Jomier JY and Brossard D. Environmental contamination with cytotoxic drugs in healthcare using positive air pressure isolators. Ann Occup Hyg 2005; 49: 619-628.

26. Fransman W, Vermuelen R and Kromhout H. Occupationel dermal exposure to cyclophosphamide in Dutch hospitals: a pilot study. Ann Occup Hyg 2004; 48: 237-244.

27. Cavallo D, Ursini CL, Pernicono B, Di Francesco A, Giglio M, Rubino FM, et al. Evaluation of genotoxic effects induced by exposure to antineoplastic drugs in lymphocytes and exfoliated buccal cells of oncology nurses and pharmacy employees. Mutat. Res/Genet Toxicol Env Mutag 2005; 587(1-2): 45-51.

28. Tompa A, Jakab M, Birò A, Magyar B, Fodor Z, Klupp $\mathrm{T}$, et al. Chemical safety and health conditions among Hungarian hospital nurses. Ann NY Acad Sci 2006; 1076: 635-648.

29. Fucic A, Jazbec A, Mijic A, Šešo-Šimic D and Tomek R. Cytogenetic consequences after occupational exposure to antineoplastic drugs. Mutat Res 1998; 416: 59-66.

30. Burgaz S, Karahalil B, Canhi Z, Terzioglu F, Ancel G, Anzion RB, et al. Assessment of genotoxic damage in nurses occupationally exposed to antineoplastics by the analysis of chromosomal aberrations. Hum Exp Toxicol 2002; 21: 129-135.

31. Sorsa M, Pyy L, Salomaa S, Nylund LL and Yager JW. Biological and environmental monitoring of occupational exposure to cyclophosphamide in industry and hospitals. Mutat Res 1988; 204: 465-479.

32. Sarto F, Trevisan A, Tomanin R, Canova A and Fiorentino M. Chromosomal aberrations, sister chromatid exchange, and urinary thioethers in nurses handling antineoplastic drugs. Am J Ind Med 1990; 18: 689-695.

33. Bonassi S, Hagmar L, Strömberg U, Montagud AH, Tinnerberg H, Forni A, et al. Chromosomal aberrations in lymphocytes predict human cancer indipendently of exposure to carcinogens. Canc Res 2000; 60: 1619-1625.

34. Bonassi S, Znaor A, Norppa H and Hagmar L. Chromosomal aberrations and risk of cancer in humans: an epidemiologic perspective. Cytogenet Genome Res 2004; 104: 376-382.

35. Hagmar L, Bonassi S, Stromberg U, Brogger A, Knudsen LE, Norppa H, et al. Chromosomal aberrations in lymphocytes predict human cancer: a report from the European Study Group on Cytogenetic Biomarkers and Health (ESCH). Canc Res 1998; 58: 4117-4121.

36. Hagmar L, Brogger A, Hansteen IL, Heim S, Hogstedt $\mathrm{B}$, Knudsen L, et al. Cancer risk in humans predicted by increased levels of chromosomal aberrations in lymphocytes: Nordic study groupon the health risk of chromosome damage. Canc Res 1994; 54: 2919-2922.

37. Rass U, Ahel I and West SC. Defective DNA repair and neurodegenerative disease. Cell 2007; 130: 991-1004.

38. Ljungman M and Lane DP. Transcription guarding the genome by sensing DNA damage. Nat Rev Canc 2004; 4: $727-737$.

39. Anderson D, Francis AJ, Godbert P, Jenkinson PC and Butterworth KR. Variability in chromosome aberrations, sister chromatid exchanges, and mitogen-induced blastogenesis in peripheral lymphocytes from control individuals. Environ Health Persp 1993; 104: 83-88.

40. Kašuba V, Šentija K, Garaj-Vrhovac V and Fučić A. Chromosome aberrations in peripheral blood lymphocytes from control individuals. Mutat Res 1995; 346: 187-193.

41. Bolognesi C, Abbondandolo A, Barale R, Casalone R, Dalprà L, De Ferrari M, et al. Age-ralated increase of baseline frequencies of sister chromatid exchanges, chromosome aberrations and micronuclei in human lymphocytes. Canc Epidem Biomar Prev 1997; 6: 249-256.

42. Bender MA, Preston J, Leonard RC, Pyatt BE, Gooch PC and Shelby MD. Chromosomal aberration and sister chromatid exchange frequencies in peripheral lymphocytes of a large human population sample. Mutat Res 1988; 204: 421-433.

43. Stephan G and Pressl S. Chromosomal aberration in peripheral lymphocytes from healthy subjects as detected in first cell division. Mutat Res 1999; 446: $231-237$. 